\title{
SLAM Family Member 7
}

National Cancer Institute

\section{Source}

National Cancer Institute. SLAM Family Member 7. NCI Thesaurus. Code C95308.

SLAM family member 7 (335 aa, $\sim 37 \mathrm{kDa}$ ) is encoded by the human SLAMF7 gene. This protein is involved in signal transduction that promotes the activation of natural killer cells. 